\title{
A Review: Plastics Waste Biodegradation Using Plastics-Degrading Bacteria
}

\author{
Angga Puja Asiandu ${ }^{1 *}$, Agus Wahyudi ${ }^{2}$, Septi Widiya Sari ${ }^{3}$ \\ ${ }^{1}$ Department of Biology, Gadjah Mada University, Yogyakarta, Indonesia \\ ${ }^{2}$ Department of Biology, Sriwijaya University, Indonesia \\ ${ }^{3}$ Department of Sociology, University of Bengkulu, Indonesia
}

Received: 25/09/2020

Accepted: 25/10/2020

Published: 20/03/2021

\begin{abstract}
Plastic is a synthetic polymer that is widely used in almost every field of life. The massive use of this synthetic polymer has led to the accumulation of this polymer in the environment thus polluting the environment. The general techniques in preventing plastic waste as landfill, incineration, recycling are considered less effective as they release some hazardous materials to the environment. Thus, the appropriate technique is needed to overcome this problem. Biodegradation is an enzymatic degradation involving some microorganisms including bacteria. This technique can be used to prevent the plastic waste problem. Plastic waste biodegradation occurred through several steps, including biodeterioration, depolymerization, and assimilation. Within this process, bacteria will secrete many enzymes that will degrade and convert plastic polymers into microbial biomass and gases. Thus, this process has fewer even no side effect.
\end{abstract}

Keywords: Bacteria, Biodegradation, Enzymes, Plastics Waste

\section{Introduction}

Plastics are organic polymers containing molecules composed of long carbon chains back-bone formed through the polymerization (1). They are made of carbon and hydrogen, with nitrogen, sulfur, and other various organic and inorganic materials derived from fossil fuels (2). Plastics divided into natural plastics, semi-synthetic plastics, synthetic plastics, thermoplastics, and thermosetting plastics (3).

The massive plastics production has begun in the 1950s, which is generally produced for disposable use. Most of the plastics waste is non-biodegradable which takes thousands of years to be decomposed or degraded (4). In 2010, China was the highest plastic waste producer in the world with 8.8 million tons per year or $27 \%$ of the total world plastic waste production. Meanwhile, Indonesia was the second after China as the highest plastic waste-producing country in the world with 3.2 million tons per year or $10 \%$ of the total world plastic waste $(5,6,4)$. In Indonesia, approximately $15 \%$ of the individually daily wastes are plastics (7). Based on the European Plastics in 2018, total world plastic production reaches 335 million tons per year, as much as 60 million of that amount is obtained in Europe. It is estimated that the number of plastic productions will be two times greater in the next 20 years. Meanwhile, plastic bags are the most common form of plastic widely used in daily lives in the world. Although plastic products are reusable, they are still one of the main factors causing environmental pollution (8).

Corresponding Author: Angga Puja Asiandu, Department of Biology, Gadjah Mada University, Yogyakarta, Indonesia.

E-mail: anggahasiandu@gmail.com
Plastics are daily lives related products used in almost every field of life in all countries (9). They are widely used because of their strength and durability. On the other hand, those characters lead to plastic resistance to degradation. These insoluble recalcitrant polymers take many years to be naturally degraded in the environment. This problem encourages plastic waste pollution that threatens many living things, including humans (10).

The uncontrolled plastics uses started several decades ago have caused many environmental problems related to the disposal uses and pollutions of plastics waste. The decomposition process of plastic polymers takes thousands of years. People usually burn plastics waste to overcome the accumulation of plastics waste in the environment yet the burning of plastics waste leads to air pollution. It releases toxic compounds, $\mathrm{CO}_{2}$, and dioxins, into the air. Those released gases cause lung diseases and cancer (11). As plastics waste is a pollutant polluting the land, air, and water ecosystem (12), threatening various living things (10), therefore the appropriate processing method of plastic waste is necessarily needed to be carried out. The application of reuse, reduce, and recycle is now widely applied to prevent the problem caused by plastics waste. However, this method is less effective, especially for plastics waste that has been mixed with other types of waste (8). Also, landfill plastics waste processing requires large space, and incineration plastics waste processing can produce toxic gases into the environment (13). Thus the more effective and environmentally safe processing plastics waste method is needed. Biodegradation is considered as a more profitable and more effective method to prevent this worldwide problem. 
Biodegradation involves many kinds of plastics degrading microorganisms $(14,15)$ as bacteria, such as D.nigrificans, and Pseudomonas alcaligenes (16). They can produce various enzymes, both intracellular and extracellular, that can degrade plastic polymers to protect the environment $(14,15)$, and to stop plastics polluting the land, air, and water (10).

\section{Type of Plastics}

Plastics generally divided into two categories, thermoplastics and thermosets. Thermoplastics are a group of plastics that can be melted when heated and hardened when cooled. Thermoplastics are including Polyethylene Terephthalate (PET), Polyethylene (PE), Low-Density Polyethylene (LDPE), High-Density Polyethylene (HDPE), Polystyrene (PS), Expanded polystyrene (EPS), Polyvinylchloride (PVC), Polycarbonate, Polypropylene (PP), Polylactic acid (PLA) and Polyhydroxyalkanoates (PHA). Meanwhile, thermosets are plastics which their chemical structures can be changed when heated thus can not be re-melted. Thermoset plastics are including Polyurethane (PUR), Phenolic resins, Epoxy resins, Silicone, Vinyl ester, Acrylic resins, Ureaformaldehyde (UF) resins (4).

Polyethylene terephthalate (PET) is a transparent and thin plastic that commonly used as a wrapper for various foods and drinks. Low-density polyethylene (LDPE) is a flexible and strong heat-resistant plastic usually used as a drink container. High-density polyethylene (HDPE), made from heat-resistant petroleum, is commonly used as plastic bags. While Polyvinyl chloride (PVC) is a synthetic plastic containing many chemical additives such as heavy metals, dioxins, BPA, and phthalates resulting in various health problems as bronchitis and cancer. This plastic is widely used as a wrapper, such as vegetable oil wrapper. Polypropylene (PP), strong and semi-permanent plastic, commonly used for medicine packaging. Polystyrene (PS) is a petroleum-based plastic that contains benzene, a carcinogenic compound. This plastic widely used as cutleries. Polycarbonate is a plastic that contains hazardous BPA material, this plastic is usually used as a reusable bottle $(17,18)$. Meanwhile, the most common single-use plastics are LDPE, HDPE, PET, PS, EPS, and PP (4).

Based on Plastic Europe 2018, In Europe, the highest plastic demands are LDPE, HDPE, polypropylene, polyvinyl chloride, polyurethane, polystyrene, and polyethylene terephthalate. The need for LDPE is $17.5 \%$ and HDPE $12.3 \%$. While the need for polypropylene is $19.3 \%$, polyvinyl chloride $10.2 \%$, polyurethane $7.7 \%$, polystyrene $7.4 \%$, and polyethylene terephthalate is $7.4 \%$ (19).

In addition to nonbiodegradable synthetic plastics, biodegradable plastics are now being developed and used. Biodegradable plastics and polymers are materials that are now widely used in various industries. The use of biodegradable plastics is related to environmental problems due to the recalcitrant characteristic of petroleum-based plastics waste. Some biodegradable plastics are polylactic acid (PLA) and polybutylene adipate-co-terephthalate $(20,21)$. Although PLA is biodegradable, the polymer still requires a long time to be degraded in nature. The complete biodegradation process of a biodegradable polymer in nature takes months or even years (21).

\section{Plastics Waste Problems}

The plastics degradation process in the environment takes up 20 to 100 years, even reaching 500 years to be degraded completely (22). Furthermore, the degradation of plastic bags and styrofoam containers spend 1000 years (4). It causes negative impacts on the environment as decreasing soil fertility that contaminated with plastics waste, contaminating water by plastic constituents, interfering soil-decomposing organisms, and accumulating toxic compounds through the food chains. Also, buried plastic waste blocks waterways cause flooding (22).

Plastics waste in both terrestrial and aquatic environments is the main problem of ecosystem balance. It will be worse when the plastics have been transformed into invisible microplastics that are harder to overcome. The large amount of plastics waste dominated by plastic bags has caused various respiratory and digestive system problems for thousands of species. Ingested plastic waste by animals, mainly aquatic animals such as fish, leads to bioaccumulation of the toxic compounds contained in the plastic waste. Then the plastic contaminated fish possibly consumed by humans resulting in many health problems. It is estimated that in 2050 as many as $99 \%$ of seabirds will be exposed to plastic waste through ingestion (4).

Plastics waste on the land can be broken down by sunlight into smaller parts or fragments polluting soil and water. Those toxic fragments may be involved in food chains threatening many living things. For instance, polyethylene is gravely hazardous for many aquatic species as aquatic mammals, sea turtles, and waterbirds when it is consumed accidentally (11).

Plastics waste burning is not an effective solution to solve plastics accumulation problems. That process releases toxic gases into the environment including dioxins, heavy metals, PCBs, and furans causing various respiratory system diseases $(23,18)$. Furthermore, the plastic burning produces $\mathrm{CO}_{2}$ into the air, the gas is related to global warming. It will trap solar heat that increases the earth's surface temperature $(24,18)$.

The accumulated plastics waste on the land is hard to degrade. It will inhibit the water infiltration into the soil (11), leads to soil infertility. The plastics waste accumulation on the land reduces the availability of oxygen in the soil. The amount of plastics waste in the soil causes the reduction of soildecomposing organisms, thus decomposition of organic and inorganic materials will be decreased that affects the soil fertility and inhibits plant growth (22).

\section{Plastics Hazardous Substances}

Plastics contain some hazardous substances affecting human health. Dangerous plastic components such as bisphenol A found in PC and PVC can cause the reproductive system disorders, mainly the ovaries. Phthalates contained in PS and PVC lead to testosterone disorders and interfere with sperm motility. The styrene monomers as those found in polystyrenetype plastics are carcinogenic. Nonylphenol contained in PVC causes estrogen disorders. Meanwhile, dioxins, persistent organic pollutants (POPs), polycyclic aromatic hydrocarbons (PAHs), and polychlorinated biphenyls (PCBs) found in almost all plastic types resulting in various health problems. Dioxins are carcinogens interfering with testosterone disorders. POPs can disrupt the nervous and reproductive systems. PAHs associated with the reproductive system and development disorders, and PCBs related to thyroid hormone disorders $(25,18)$. 


\section{General Plastics Waste Management}

Plastics waste landfill and incineration are two commonly used plastic waste management methods. However, these two methods are considered as the managing plastic waste processes which have side effects on the environment as they release various toxic gases into the air, besides landfill also requires a large space. Plastics recycling activities are also relatively ineffective in dealing with the abundance of plastic waste (13).

The application of reuse, reduce, and recycle is now widely promoted in addition to solve plastic waste problems. It is appropriate for postindustrial plastics, yet it is not effective for plastics that have been used or consumed by people that are usually mixed with other organic and inorganic wastes. Afterward, chemical methods of plastics waste management systems are influenced by several factors and conditions related to the polymer constituents of each plastic (8).

\section{Plastics Biodegradation}

A plastics waste processing effective method is needed (14, 15) to balance the increasing uses of plastics every year (26). It is Biodegradation. Biodegradation is an effective, profitable, and economically valuable plastics waste processing method. The ability of many microorganisms to break down plastic polymers is an advantage that can be used in dealing with problems arising from the increasing accumulation of plastics waste every day. Some microorganisms produce various kinds of enzymes, both intracellular and extracellular, catalyze plastic polymers degradation into safe smaller fragments $(14,15)$. The utilization of microbial cells directly to degrade plastic C-C bonds is considered more effective (27). Biodegradation is a specific enzymatic process. Certain enzymes break down certain substrates (28).

The plastic waste biodegradation process occurs through several stages, including biodeterioration, depolymerization, and assimilation. Biodeterioration is a cooperation between several microbes and abiotic factors that breaks down polymers into smaller ones. This process will be continued with depolymerization. Depolymerization occurs in which microbes secrete catalytic compounds in the form of enzymes and free radicals to form biofilms helping them to break the polymer chains progressively (29).

Biodeterioration is a process of changing or modifying plastic polymers carried out by some microorganisms on the plastic surface. The changes include chemical, physical, and mechanical changes (30). This process will be accelerated by biofilms formed by microorganisms on the plastic surface. A biofilm is a form of living things community. Microbes attach themselves and colonize the surface of an object to form biofilms assisted by an extracellular compound produced by them. In the form of biofilms, microbial cells attach one to another in a polymer matrix containing polysaccharides and proteins (13). Extracellular polymeric substances (EPS) produced by microorganisms help them to break down the plastic surface $(31,32)$. EPS consists of polysaccharides, proteins, and nucleic acids (33).

EPS penetrates the plastic surface pores causing enlargement of the pores. It is enhanced microbes, bacteria, to damage plastic polymers, to form holes, and to encourage the physical deterioration of plastic polymers $(31,32)$. Also, the formation of biofilms on plastic surfaces encourages the formation of various kinds of acid compounds changing the $\mathrm{pH}$ of plastic polymers leads to chemical plastic deterioration causing changes of the polymer microstructures. These acids are including nitrous acid, nitric acid or sulfuric acid, citric, fumaric, gluconic, glutaric, glyoxylic, oxalic, and oxaloacetic (32). The plastic surface damages associated with metabolites and extracellular enzymes released by bacteria (34)

Depolymerization of the plastic constituents is carried out by depolymerase enzymes. The results of this reaction can be in the form of oligomers, dimers, and monomers that are simpler than polymers. They will be further processed according to the presence of oxygen molecules in metabolism. Aerobic degradation of those components will produce microbial biomass, $\mathrm{CO}_{2}$, and $\mathrm{H}_{2} \mathrm{O}$. While anaerobic degradation will change those components into microbial biomass, $\mathrm{CO}_{2}, \mathrm{H}_{2} \mathrm{O}$, and $\mathrm{CH}_{4}$ or $\mathrm{H}_{2} \mathrm{~S}$ (35).

Extracellular and intracellular depolymerase enzymes secreted by microbes have important roles in plastic waste degradation. During the degradation process, the released enzymes will break down complex polymers into smaller and simpler chains. These decomposed small molecules will be easily dissolved in water then absorbed through microbial semipermeable cell membranes to be used as carbon and energy sources. Assimilation occurs in microbial cytoplasms in which the metabolic process occurs to produce energy, biomass, food reserves, primary and secondary metabolites (29). After degraded into smaller ones, plastic fragments such as monomers will enter the cells. These components enter the microbial cell metabolism system to undergo a subsequent degradation process to form energy and biomass for microorganisms. Even though monomers have formed, sometimes they do not fully assimilated. They will be released outside of the cells and will be used by other microorganisms that have a suitable assimilation pathway for those monomers (32).

The next process of biodegradation is mineralization. Mineralization is the final metabolic process of plastic waste toxic compounds. This process changes those hazardous compounds into more environmentally safe compounds (36). Mineralization is a process of converting biodegradable materials or biomass into gases, water, salt, minerals, and other residues. The formed gases include carbon dioxide, methane, and nitrogen components. The mineralization process will be ended when all biodegradable compounds have been consumed by microorganisms and all carbons are converted to carbon dioxide $(37,38)$.

\section{Plastics Degrading Bacteria}

Many plastics degrading bacteria have been widely reported by researchers as compiled in table 1 . Some of PE degrading bacteria are including D.nigrificans and Pseudomonas alcaligenes isolated from plastic waste contaminated soil (16), Enterobacter sp. D1 isolated from the guts of Galleria mellonella (39) and P.putida MTCC 2475 isolated from garden soil. P.putida MTCC 2475 reduced milk cover weight about $63.1-73.3 \%$ within 1 month incubation (40). In the Enterobacter sp. D1 treated solution there was increasing of alcohol, esters, acidic compounds, ethyl decanoate, and 6methyl-5-hepten-2-ol. Alcohol, alkaline, hydrocarbon, esters, and acid compounds indicate bacterial metabolism in degrading PE $(41,39)$. That process involves various oxidoreductase enzymes (39). 
Tabel 1: Plastics Degrading Bacteria

\begin{tabular}{|c|c|c|c|c|c|c|}
\hline $\begin{array}{l}\text { Plastic } \\
\text { Types }\end{array}$ & Bacteria & Isolate Sources & $\begin{array}{l}\text { Observation of } \\
\text { Degradation }\end{array}$ & Media & $\begin{array}{l}\text { Incubation } \\
\text { Time }\end{array}$ & References \\
\hline \multirow{11}{*}{ PE } & $\begin{array}{l}\text { Bacillus } \\
\text { amylolyticus }\end{array}$ & Garbage Soil & $32 \%$ of PWL & Culture Broth Medium & 1 Month & $(42)$ \\
\hline & Bacillus subtilis & Garbage Soil & $14 \%$ of PWL & Culture Broth Medium & 1 Month & (42) \\
\hline & $\begin{array}{l}\text { Desulfotomaculu } \\
\text { m nigrifans }\end{array}$ & $\begin{array}{l}\text { Plastic Contaminated } \\
\text { Soil }\end{array}$ & $16.2 \%$ of PWL & Nutrient Broth & 1 Month & $(16)$ \\
\hline & $\begin{array}{l}\text { Enterobacter sp. } \\
\text { D1 }\end{array}$ & $\begin{array}{l}\text { Isolated from Gut of } \\
\text { Galleria mellonella }\end{array}$ & $\begin{array}{l}1.98 \% \text { of CD } \\
1.98 \% \text { of OI }\end{array}$ & $\begin{array}{l}\text { A Carbon-Free Source } \\
\text { Agar Solid Medium }\end{array}$ & 31 Days & $(39)$ \\
\hline & $\begin{array}{l}\text { Pseudomonas } \\
\text { alcaligenes }\end{array}$ & $\begin{array}{l}\text { Plastic Contaminated } \\
\text { Soil }\end{array}$ & $16.2 \%$ of PWL & Nutrient Broth & 1 Month & $(16)$ \\
\hline & $\begin{array}{l}\text { Pseudomonas } \\
\text { fluorescens }\end{array}$ & Garbage Soil & $22 \%$ of PWL & Culture Broth Medium & 1 Month & $(42)$ \\
\hline & $\begin{array}{l}\text { Pseudomonas } \\
\text { putida }\end{array}$ & Garbage Soil & $18 \%$ of PWL & Culture Broth Medium & 1 Month & $(42)$ \\
\hline & $\begin{array}{l}\text { Pseudomonas } \\
\text { putida MTCC } \\
2475\end{array}$ & Garden Soil & $>10 \%$ of PWL & Mineral Salt Medium & 1 Month & $(40)$ \\
\hline & $\begin{array}{l}\text { Streptomyces } \\
\text { SSP2 }\end{array}$ & Soil & $8 \%$ of PWL & ATCC Medium & 1 Month & (12) \\
\hline & $\begin{array}{l}\text { Streptomyces } \\
\text { SSP4 }\end{array}$ & Soil & $11 \%$ of PWL & ATCC Medium & 1 Month & $(12)$ \\
\hline & $\begin{array}{l}\text { Sterptomyces } \\
\text { SSP14 }\end{array}$ & Soil & $19 \%$ of PWL & ATCC Medium & 1 Month & $(12)$ \\
\hline \multirow{24}{*}{ LDPE } & $\begin{array}{l}\text { Actinobacter } \\
\text { ursingii }\end{array}$ & Soil and Plastic Waste & Color Zone on the Medium & Solid MSM & 3 Days & $(48)$ \\
\hline & $\begin{array}{l}\text { Alcanivorax } \\
\text { borkumensis }\end{array}$ & $\begin{array}{l}\text { Marine Plastic Waste } \\
\text { Sedimentations }\end{array}$ & $3.5 \%$ of PWL & $\begin{array}{l}\text { Liquid Medium Containing } \\
0.05 \% \text { Hexadecane }\end{array}$ & 80 Days & $(50)$ \\
\hline & \multirow{2}{*}{$\begin{array}{l}\text { Bacillus } \\
\text { carbonipphilus }\end{array}$} & \multirow{2}{*}{$\begin{array}{l}\text { LDPE Contaminated } \\
\text { Soil }\end{array}$} & $25 \%$ of PWL & Mineral Broth & \multirow{2}{*}{2 Months } & \multirow[b]{2}{*}{$(45)$} \\
\hline & & & $34.55 \%$ of $\mathrm{PWL}$ & Mineral Agar & & \\
\hline & \multirow{2}{*}{$\begin{array}{l}\text { Bacillus } \\
\text { coagulans }\end{array}$} & \multirow{2}{*}{$\begin{array}{l}\text { LDPE Contaminated } \\
\text { Soil }\end{array}$} & $16 \%$ of PWL & Mineral Broth & \multirow{2}{*}{2 Months } & \multirow{2}{*}{$(45)$} \\
\hline & & & $18.37 \%$ of PWL & Mineral Agar & & \\
\hline & $\begin{array}{l}\text { Bacillus } \\
\text { licheniformis } \\
\text { KC2-MRL } \\
\end{array}$ & Soil & Plastic's Surface Damage & Mineral Salt Medium & 1 Month & (49) \\
\hline & \multirow{2}{*}{$\begin{array}{l}\text { Bacillus } \\
\text { megaterium }\end{array}$} & \multirow{2}{*}{$\begin{array}{l}\text { LDPE Contaminated } \\
\text { Soil }\end{array}$} & $34.48 \%$ of PWL & Mineral Agar & \multirow{2}{*}{2 Months } & \multirow{2}{*}{$(45)$} \\
\hline & & & $21 \%$ of PWL & Mineral Broth & & \\
\hline & \multirow[t]{2}{*}{ Bacillus nedei } & \multirow{2}{*}{$\begin{array}{l}\text { LDPE Contaminated } \\
\text { Soil }\end{array}$} & $36.07 \%$ of $\mathrm{PWL}$ & Mineral Agar & \multirow{2}{*}{2 Months } & \multirow{2}{*}{$(45)$} \\
\hline & & & $14 \%$ of PWL & Mineral Broth & & \\
\hline & \multirow[t]{2}{*}{ Bacillus smithii } & \multirow{2}{*}{$\begin{array}{l}\text { LDPE Contaminated } \\
\text { Soil }\end{array}$} & $16.40 \%$ of PWL & Mineral Agar & \multirow{2}{*}{2 Months } & \multirow{2}{*}{$(45)$} \\
\hline & & & $8 \%$ of PWL & Mineral Broth & & \\
\hline & $\begin{array}{l}\text { Bacillus sp. KC3- } \\
\text { MRL }\end{array}$ & Soil & Plastic Surface Damage & Mineral Salt Medium & 1 Month & $(49)$ \\
\hline & \multirow{2}{*}{$\begin{array}{l}\text { Bacillus } \\
\text { sporothermo- } \\
\text { durans } \\
\end{array}$} & \multirow{2}{*}{$\begin{array}{l}\text { LDPE Contaminated } \\
\text { Soil }\end{array}$} & $36.54 \%$ of $\mathrm{PWL}$ & Mineral Agar & \multirow{2}{*}{2 Months } & \multirow{2}{*}{$(45)$} \\
\hline & & & $21 \%$ of PWL & Mineral Broth & & \\
\hline & $\begin{array}{l}\text { Bacillus } \\
\text { weihenstephanens } \\
\text { is }\end{array}$ & $\begin{array}{l}\text { Hydrocarbon enriched } \\
\text { soil }\end{array}$ & $\begin{array}{l}32.61 \% \text { of TPBWL and } \\
35.64 \% \text { of ThPBWL }\end{array}$ & C-zopek-Dox Broth & 6 Months & $(82)$ \\
\hline & $\begin{array}{l}\text { Burkholderia } \\
\text { cepacia }\end{array}$ & $\begin{array}{l}\text { Hydrocarbon Enriched } \\
\text { Soil }\end{array}$ & $\begin{array}{l}31.43 \% \text { of TPBWL and } \\
36.34 \% \text { of ThPBWL }\end{array}$ & C-zopek-Dox Broth & 6 Months & $(82)$ \\
\hline & Escherichia coli & $\begin{array}{l}\text { Hydrocarbon Enriched } \\
\text { Soil }\end{array}$ & $\begin{array}{l}23.27 \% \text { of TPBWL and } \\
23.57 \% \text { of ThPBWL }\end{array}$ & C-zopek-Dox Broth & 6 Months & $(82)$ \\
\hline & $\begin{array}{l}\text { Pseudomonas } \\
\text { aeruginosa }\end{array}$ & Landfill Soil & $18.75 \%$ of PWL & Mineral Salt Broth & 45 Days & $(47)$ \\
\hline & $\begin{array}{l}\text { Pseudomonas } \\
\text { fluorescens }\end{array}$ & Garbage Soil & $22 \%$ of PWL & Culture Broth Medium & 1 Month & $(42)$ \\
\hline & $\begin{array}{l}\text { Serratia } \text { sp. KCI- } \\
\text { MRL }\end{array}$ & Soil & Plastic Surface Damage & Mineral Salt Medium & 1 Month & $(49)$ \\
\hline & $\begin{array}{l}\text { Stenotropphomon } \\
\text { as } \text { sp. KC4-MRL } \\
\end{array}$ & Soil & Plastic Surface Damage & Mineral Salt Medium & 1 Month & $(49)$ \\
\hline & $\begin{array}{l}\text { Streptomyces } \\
\text { coelicoflavus }\end{array}$ & Oil Contaminated Soil & $30 \%$ of PWL & Mineralt Salt Agar & 4 weeks & $(51)$ \\
\hline
\end{tabular}




\begin{tabular}{|c|c|c|c|c|c|c|}
\hline $\begin{array}{l}\text { Plastic } \\
\text { Types }\end{array}$ & Bacteria & Isolate Sources & $\begin{array}{l}\text { Observation of } \\
\text { Degradation }\end{array}$ & Media & $\begin{array}{l}\text { Incubation } \\
\text { Time }\end{array}$ & References \\
\hline & NBRC $15399^{\mathrm{T}}$ & & & & & \\
\hline & $\begin{array}{l}\text { Streptomyces } \\
\text { SSP2 }\end{array}$ & Soil & $6 \%$ of PWL & ATCC Medium & 1 Month & (12) \\
\hline & $\begin{array}{l}\text { Streptomyces } \\
\text { SSP4 }\end{array}$ & Soil & 9\% of PWL & ATCC Medium & 1 Bulan & (12) \\
\hline & $\begin{array}{l}\text { Sterptomyces } \\
\text { SSP14 }\end{array}$ & Soil & $17 \%$ of PWL & ATCC Medium & 1 Month & (12) \\
\hline HDPE & $\begin{array}{l}\text { Ochrobacterum } \\
\text { anthropi }\end{array}$ & Landfill Soil & $20 \%$ of PWL & Mineral Salt Broth & 45 Days & $(47)$ \\
\hline \multirow{2}{*}{ PP } & Bacillus cereus & Mangrove sediment & $12 \%$ of PWL & Mineral Broth & 40 Days & (53) \\
\hline & $\begin{array}{l}\text { Sporosacrina } \\
\text { globispora }\end{array}$ & Mangrove sediment & $11 \%$ of PWL & Mineral Broth & 40 Days & (53) \\
\hline \multirow{4}{*}{ PS } & Bacillus subtilis & Culture & $\begin{array}{l}20 \% \text { of PWL in NB and } \\
58.82 \% \text { of PWL in BHB }\end{array}$ & NB and BHB & 1 Month & $(54)$ \\
\hline & $\begin{array}{l}\text { Pseudomonas } \\
\text { auroginosa }\end{array}$ & Culture & $\begin{array}{l}5 \% \text { of PWL in NB and } \\
11 \% \text { of PWL in BHB }\end{array}$ & $\mathrm{NB}$ and $\mathrm{BHB}$ & 1 Month & (54) \\
\hline & $\begin{array}{l}\text { Staphylococcus } \\
\text { aureus }\end{array}$ & Culture & $\begin{array}{l}4.76 \% \text { of PWL in NB and } \\
37.5 \% \text { of PWL in BHB }\end{array}$ & $\mathrm{NB}$ and $\mathrm{BHB}$ & 1 Month & (54) \\
\hline & $\begin{array}{l}\text { Staphylococcus } \\
\text { pyogenes }\end{array}$ & Culture & $\begin{array}{l}8.33 \% \text { of PWL in NB and } \\
11.11 \% \text { of PWL in BHB }\end{array}$ & NB and BHB & 1 Month & $(54)$ \\
\hline \multirow{3}{*}{ PET } & Bacillus subtilis & Culture & $\begin{array}{l}74.59 \% \text { of PWL in NB and } \\
1.75 \% \text { of PWL in BHB }\end{array}$ & $\mathrm{NB}$ and $\mathrm{BHB}$ & 1 Month & $(54)$ \\
\hline & $\begin{array}{l}\text { Staphylococcus } \\
\text { pyogenes }\end{array}$ & Culture & $\begin{array}{l}3.85 \% \text { of PWL in NB and } \\
3.92 \% \text { of PWL in BHB }\end{array}$ & $\mathrm{NB}$ and $\mathrm{BHB}$ & 1 Month & $(54)$ \\
\hline & $\begin{array}{l}\text { Staphylococcus } \\
\text { aureus }\end{array}$ & Culture & $\begin{array}{l}8.75 \% \text { of PWL in NB and } \\
3.85 \% \text { of PWL in BHB }\end{array}$ & $\mathrm{NB}$ and $\mathrm{BHB}$ & 1 Month & $(54)$ \\
\hline PHB & $\begin{array}{l}\text { Streptomyces } \\
\text { lydicus MM10 }\end{array}$ & $\begin{array}{l}\text { Soil, Sand and } \\
\text { Wastewater }\end{array}$ & $\begin{array}{l}\text { Hydrolysis Zone Formed } \\
\text { on PHB Containing } \\
\text { Medium }\end{array}$ & $\begin{array}{l}\text { Turbid Medium } \\
\text { Containing PHB as Carbon } \\
\text { Source }\end{array}$ & 7 Days & $(56)$ \\
\hline \multirow{2}{*}{ PLA } & $\begin{array}{l}\text { Bacillus sp. } \\
\text { MKY2 }\end{array}$ & Digester Sludge & Morphological Damage & PLA-Agar Plate & 40 Days & (21) \\
\hline & $\begin{array}{l}\text { Pseudomonas sp. } \\
\text { MKY1 }\end{array}$ & Digester Sludge & Morphological Damage & PLA-Agar Plate & 40 Days & (21) \\
\hline
\end{tabular}

PWL: Plastic's Weight Loss; TPBWL: Thin Plastic Bag's Weight Loss; ThPBWL: Thin Plastic Bag's Weight Loss; CD: Carbon Decreasing; OI: Oxygene Increasing; NB: Nutrient Broth; BHB: Bushnell Hash Broth.

Four polyethylene plastic degrading bacteria isolated from soil were also reported by Patil (42). They were Bacillus amylolyticus, B.subtilis, Pseudomonas putida, and Pseudomonas fluorescens. These bacteria were separately incubated in a broth medium containing polyethylene films and incubated for a month. Based on the research, B.amylolyticus was able to reduce $32 \%$ of polyethylene film weight, followed by P.fluorescens with $22 \%$, P.putida $18 \%$, and B.subtilis $14 \%$. FTIR analysis stated that there was a rapid process of carbon chain degradation through wave absorption. These bacteria break down polythene polymers then serve them as their carbon source (42). P.aeruginosa and P.stutzeri are also included as PE degrading bacteria (15). Pseudomonas spp. have an inducible operon system initiating the formation of certain enzymes that are useful in unusual carbon sources metabolisms. Enzymes produced by Pseudomonas spp. are including serine hydrolase, esterase, and lipase (43).

The other 5 isolates of polyethylene degrading bacteria were successfully isolated from dumped soil. The five bacteria were Bacillus amylolyticus, Bacillus firmus, Pseudomonas putida, Pseudomonas fluroscence, and Bacillus subtilis. They were incubated in culture broth media for a month. Based on that research, B.amylolyticus was able to reduce plastic samples about $\quad 20 \%$, B.firmus $12 \%$, P.putida $30 \%$, P.fluroscence $16 \%$, and B.subtilis $22 \%$. FTIR analysis showed that the plastics were damaged (44).

Bacillus spp. are potential LPDE degrading agents. By using agar minerals incubated for two months, B.carbonipphilus was able to degrade LDPE about $34.55 \%$. Meanwhile, B.sporothermo-durans degraded the sample about $36.54 \%$, B.sporothermodurans degraded it about $36.54 \%$, B.coagulans degraded the sample about $18.37 \%$, B.neidei decreased the plastic's weiht about $36.07 \%$, B.smithii degraded it about $16.0 \%$, and B.megaterium degraded it about $34.48 \%$. In Mineral Broth media, B.carbonipphilus degraded LDPE about $25 \%$, B.sporothermodurans $21 \%$, B.coagulans $16 \%$, B.neidei $14 \%$, B.smithii $8 \%$, and B.megaterium $21 \% \quad$ (45). When microorganisms adhere to the plastic surfaces, they will start trying to use those polymers as their carbon source (46).

The other LDPE degrading bacteria are Bacillus weihenstephanensis, Burkholderia cepacia, and Escherichia coli. Within six months, B.weihenstephanensis was able to 
reduce the weight of thick LDPE plastic bags around $32.61 \%$ and thin plastic bags about $35.64 \%$. B.cepacia can reduce the weight of thick plastic bags about $31.43 \%$, and $36.34 \%$ for thin plastic bags. Whereas E.coli reduced $23.72 \%$ of thick plastic bags weight and $23.57 \%$ for thin plastic bags (Mukherjee and Chatterjee, 2014). LDPE weight reduction by Pseudomonas aeruginosa was $18.75 \%$ within a month (47). Moreover, P.fluorescens and Actinobacter ursingii are also considered as LDPE degrading bacteria (48).

Furthermore, Jamil et al. (49), reported that Serratia sp. KCI-MRL, Bacillus licheniformis KC2-MRL, Bacillus sp. KC3MRL, and Stenotrophomonas sp. KC4-MRL isolated from the soil in Khasmir Smast, Pakistan, were able to damage the surface of LDPE plastic films within one month of incubation. Harshvardhan and Jha, cited from Jamil et al. (49) stated that LDPE biodegradation through a series of enzymatic reactions involving various enzymes that catalyze chemical changes of plastic polymers such as oxidation, reduction, hydrolysis, esterification, and molecular inner conversion.

Another studi also reported that Alcanivorax borkumensis was able to form large biofilms on the surface of LDPE waste. This bacterium is a species of hydrocarbondegrading bacteria which able to degrade LDPE (50). Based on Golyshin et al., and Sabirova et al., the LDPE degradation mechanism by this bacterium is carried out through several enzymatic reactions involving various enzymes, such as alkane hydroxylase (alkB1, alkB2), cytochrome P50, and Ferredoxin (50).

The ability of actinomycetes in degrading plastic waste was also reported by some researchers. Some LDPE degrading actinomycetes including Streptomyces coelicoflavus NBRC 15399T (51), Streptomyces SSP2, Streptomyces SSP4, and Streptomyces SSP14 are potential agents of plastic waste biodegradation. They are also considered to be able to produce bioemulsifier. Bioemulsifier is a molecule produced by microorganisms during the degradation of plastic polymers. The microorganisms used in that study were able to produce biosurfactants that are also important in plastics degradation (12). Actinomycetes produce various kind of metabolites which play a vital role in plastics degradation (52).

One of the HDPE degrading bacteria is Ochrobacterum anthropi. This bacterium degraded HDPE film by $20 \%$ in 45 days (47). PP degrading bacteria are including Bacillus cereus and Sporosarcina globispora. The plastic degradation ability of B.cereus was 0.003 grams per day, while S.globispora was 0.002 grams per day (53). Two PLA degrading bacteria including Pseudomonas sp. MKY1 and Bacillus sp. MKY2 were reported by (21). Meanwhile, B.subtilis, S.aureus, and S.pyogenes considered as important PET and PS degrading bacteria (54). Ideonella sakaiensis was also reported to degrade PET polymer $(55,19)$.

Another plastic degrading actinomycetes is Streptomyces lydicus MM10. This filamentous bacterium produces Polyhydroxybutyrate (PHB) depolymerase, an enzyme that breaks down PHB polymer (56). Furthermore, other PHB degrading bacteria are Azotobacter and Bacillus (57). Meanwhile, Moritella sp., $\quad$ Shewanella sp., $\quad$ Psychrobacter sp., and Pseudomonas sp. play a role in PCL degradation (58). Under the appropriate conditions and environments, various kinds of bacteria can accumulate Poly-hydroxybutyrate (PHB) in their cells then break down that polymer catalyzed by PHB depolymerase (56).

\section{Enzymes Involved in Plastics Biodegradation}

Many microbes produce various kinds of important enzymes in plastic biodegradation. Enzymes such as laccase, lignin peroxidase, manganese peroxidase, lipase, esterase, and amylase are potential catalysts of plastic constituent polymers degradation $(59,60)$. Lignin peroxidase, manganese peroxidase, and laccase are the three main lignolytic enzymes $(61,62)$. Lignolytic enzymes are including phenol oxidase or laccase, heme peroxidase consisting of lignin peroxidase, manganese peroxidase, and versatile peroxidase $(63,62)$.

There are two reactions involved in the polymer biodegradation process, hydrolysis and oxidation. Hydrolysis is the breaking down of polymers catalyzed by hydrolases enzymes, while oxidation is a biodegradation process catalyzed by various oxidoreductase enzymes. Hydrolase enzymes catalyze the hydrolyzing reactions of esters, carbonates, amides, and glycosidic bonds of various hydrolyzed polymers to produce monomers. Meanwhile, oxidoreductase enzymes catalyze oxidizing and reducing reactions of ethylene, carbonate, amide, urethane, and others $(59,60)$.

The polymers hydrolysis process usually includes a reaction involving three amino acid residues including aspartate, histidine, and serine. Aspartate will interact with the histidine ring to form hydrogen bonds. The histidine ring will interact with serine. Histidine conducts the deprotonating process with serine to form a nucleophilic alkoxide (-O), a group attacking the ester bonds. This process results in an alcohol tip and an acyl-enzyme complex. Then, water attacks the acyl-enzyme complex to form a carboxyl-end and free enzyme that will be further processed by microorganisms $(64,35)$. Bacillus sp. $\mathrm{BCBT} 21$ is one of the hydrolases producing bacteria. It produces lipase, CMCase, xylanase, chitinase, and protease that are important in the degradation of plastic polymers (65).

When some polymer compounds can not be degraded by certain enzymes, the other appropriate enzymes will work together to break down those compounds. This phenomenon is known as oxidation. For instance, monooxygenase and dioxygenase will be coalesced to form a more fragmented alcohol or peroxyl groups. The further reaction will be catalyzed by peroxidase, breaking down these components into smaller components. Peroxidases catalyze the reaction between a peroxyl molecule and an electron acceptor such as phenol, phenyl, amino, carboxyl, thiol, or unsaturated aliphatic compound $(64,35)$.

As the first step of PE degradation, carbonyl grub of the PE is converted into alcohol. The process is catalyzed by the monooxygenase enzyme. Then it will be converted into an aldehyde catalyzed by alcohol dehydrogenase. Furthermore, the formed aldehyde will be converted into fatty acids by the aldehyde dehydrogenase. They will be entered into the $\beta$ oxidation process for further processing inside microbial cells $(66,38)$. Meanwhile, the oxidation process carried out by laccase breaks down polyethylene polymers into carboxylic acids. These formed acids will be entered fl-oxidation with coenzyme-A. This reaction breaks the two carbon fragments of the carboxylic acids to form acetyl-CoA. This result will be included in the citric acid cycles for further metabolism. In the end, water and carbon dioxide will be produced as the final 
products of PE biodegradation carried out by microorganisms catalyzed by laccase (67).

PET degradation by Ideonella sakaiensis catalyzed by two correlated types of enzymes, PETase (PET-digesting enzyme) and MHETase (MHET-digesting enzyme). PETase converts PET into mono (2-hydroxyethyl) terephthalic acid or MHET. That process also produces secondary products such as terephthalic acid (TPA) and bis (2-hydroxyethyl)-TPA. Furthermore, the MHETase enzyme converts the formed MHET into two monomers, TPA and ethylene glycol or EG $(55,68)$.

Polyurethane degraded by polyurethane degrading bacteria such as Pseudomonas chlororaphis $(69,70)$. Two proteolytic enzymes used in polyurethane polyester degradation are papain and urease. Polymer degradation by papain is carried out by the hydrolysis reaction of urethane and urea bonds. This hydrolysis reaction produces free amines and hydroxyl groups (71, 62). Meanwhile, aliphatic polyester such as PEA, PES, PPA, and PBA can be degraded by hydrolase enzymes including lipase, PEA depolymerase, and PHB depolymerase (72, 38). PHB depolymerase is widely produced by some bacteria including Alcaligenes faecalis, Rhodospirillum rubrum, B.megaterium, A.beijerinckii and Pseudomonas lemoignei (73, 56).

PVA can be degraded by Pseudomonas spp. Those bacteria secrete a PVA degrading enzyme, polyvinyl alcohol dehydrogenase (PVADH). PVA degradation occurs through two stages. The first stage is the conversion of the 1,3-glycol structure to $\beta$-ketone through random oxidative dehydrogenation reactions or hydroxyl group oxidations to form a monoketone structure. This process is catalyzed by alcohol oxidase. The second step is breaking down the carbon-carbon bond and changing the ketone groups to carboxylic $(37,38)$. Two possible mechanisms occurred in this step. The first possibility is the hydrolysis of the $\beta$-diketone structure of oxidized PVA (oxiPVA) catalyzed by $\beta$-diketone hydrolase (oxiPVA hydrolase). The second possibility is the aldolase reaction involving the monoketone structure of the oxidized PVA (74, 38).

Another important plastic degradation catalyst is the PHA hydrolase enzyme. It is classified as serine hydrolase that attacks the branch chains and cyclic components of PHA (75, 62). Meanwhile, PCL degradation can be carried out by microorganisms by producing PCL enzymes hydrolases, lipases, and esterases. PCL can be degraded by some microbes such as Rhizopus arrhizuz $(76,38)$. PLA can be hydrolyzed by lipase, proteinase $\mathrm{K}$, and polyester polyurethane depolymerase $(77,38)$. Moreover, nylon degradation involves the hydrolysis reaction of amine bonds (-CONH-) of Nylon polymers that forms 12-amino dodecanoic acid. This acid then oxidized to carboxyl and other products. One of the nylons degrading bacteria is Geobacillus thermocatenulatus $(78,38)$.

\section{Factors Affecting Biodegradation}

Biodegradation is influenced by several factors including the chemical structure of the polymers, the phase structure (amorphous or crystalline) of plastic polymers, molecular weight, miscibility of the polymer's constituent. Moreover, the presence of hydrolyzed and oxidized compounds also affect the biodegradation process carried out by microorganisms. Other factors that also affect the rate of the biodegradation process are hydrophobicity or hydrophilicity compatibility between the microorganism's surface and the plastic film surface, the polymeric bonds, and the level of plastic surface roughness. Environmental factors also affect the biodegradation process, including temperature and humidity $(79,80)$. Nutrition also has important roles in the biodegradation (81).

\section{Conclusions}

Biodegradation of plastic waste using plastics degrading bacteria is a valuable plastic waste treatment that must be implemented to maintain the environment quality of the problems caused by plastic waste. This process has less even no side effect that pollutes the environment. Plastic biodegradation involves some hydrolase and oxidase enzymes produced by many microbes including bacteria. This enzymatic process breaks down the recalcitrant plastic polymers into microbial biomass and other environmentally safe compounds throughout several steps, including biodeterioration, depolymerization, assimilation, and mineralization. Optimization of proper environmental factors is the main factor to enhance the ability of bacteria to degrade plastics waste.

\section{Aknowledgment}

We thank all the researchers for their valuable and important studies about plastic waste biodegradation using plastic degrading bacteria that cited by us in this review.

\section{Ethical issue}

Authors are aware of, and comply with, best practice in publication ethics specifically with regard to authorship (avoidance of guest authorship), dual submission, manipulation of figures, competing interests and compliance with policies on research ethics. Authors adhere to publication requirements that submitted work is original and has not been published elsewhere in any language.

\section{Competing interests}

The authors declare that there is no conflict of interest that would prejudice the impartiality of this scientific work.

\section{Authors' contribution}

All authors of this study have a complete contribution for data collection, data analyses and manuscript writing.

\section{References}

1 Koushal V, Sharma R, Sharma M, Sharma R, Sharma V. Plastics: Issues Challenges and Remediation. International Journal of Waste Resources. 2014 Feb 10;4(1):1-6.

2 Kumari P, Murthy NS. A Novel Mathematical Approach for Optimization of Plastic Degradation. International Journal of Engineering Trends and Technology. 2013 August; 4(8):3539-42.

3 Kumar S, Das ML, Rebecca J, Sharmila S. Isolation and identification of LDPE degrading fungi from municipal solid waste. Journal of Chemical and Pharmaceutical Research. 2013 May; 5(3):78-81.

4 UNEP. Single-Use Plastics: A Roadmap for Sustainability. 2018 June 5 .

5 Jambeck R, Geyer R, Wilcox C, Siegler TR, Perryman M, Andrady A, Narayan R, Law KL. Plastic waste inputs from land into the ocean. Science. American Association for the Advancement of Science. 2015 Feb 12;347(6223):768-71. 
6 Geyer R, Jambeck JR, Law KL. Production, Use, and Fate of All Plastics Ever Made. Science Advaces. 2017 Jul;3(7):1-5.

7 Arico Z, Jayanthi S. Pengolahan Limbah Plastik Menajdi Produk Kreatif sebagai Peningkatan Ekonomi Masyarakat Pesisir. Martabe: Jurnal Pengabdian Masyarakat. 2017 Nov 13;1(1): 1-6.

8 Drzyzga O, Prieto A. Plastic Waste Management, a Matter for the Community. Microbial Biotechnology. 2018 Nov 8;12(1):66-8.

9 Mrowiec B. Plastic Pollutans in Water Environtment. Environmental Protection and Natural Resources. 2017; 28(4): 51-5.

10 Sowmya H, Ramalingappa V, Krishnappa, Thippeswamy B. Low Density Polyethylene Degrading Fungi Isolated from Local Dumpsite of Shivamogga District. International Journal of Biological Research. 2014 May 31;2(2): 39-43.

11 Kale SK, Deshmukh AG, Dudhare MS, Patil VB. Microbial Degradation of Plastic: a Review. Journal of Biochemical Technology. 2015 Dec 25;6(2): 952-61.

12 Soud SA. Biodegradation of Polyethylene LDPE Plastic Waste using Locally Isolated Streptomyces sp. Journal of Pharmacetical Sciences and Research.. 2019;11(4):1333-9.

13 Kumar VR, Kanna GR, Elumalai S. Biodegradation of Polyethylene by Green Photosynthetic Microalgae. Journal of Bioremediation\&Biodegradation. OMICS Publishing Group. 2017;8(1):1-8

14 Okmoto K, Izawa M, Yanase H. Isolation and Application of a Styrene-Degrading Strain of Pseudomonas putida to Biofiltration. Journal of Bioscience and Bioengineering. Elsevier. 2003 Jan;95(6):633-6.

15 Agrawal P, Singh RK. Breaking Down of Polyethylene by Pseudomonas Species. International Journal of Scientific\&Engineering Research. 2016 March;7(3):124-7.

16 Begum MA, Varalakshmi B, Umamagheswari K. Biodegradation of Polythene Bag using Bacteria Isolated from Soil. International Journal of Current Microbiology and Applied Sciences. 2015; 4(11): 674-80.

17 Proshad R, Islam MS, Kormoker T, Haque MA, Rahman MM Mithu MMR. Toxict Effect of Plastic on Human Health and Environment: a Sequences of Health Risk Assessment in Bangladesh. International Journal of Health. 2018;6(1):1-5.

18 Alabi OA, Ologbonjaye KI, Awosolu O, Alade OE. Public and Environmental Health Effects of Plastic Wastes Disposal: A Review. Journal of Toxicology and Risk Assessment. 2019 Apr 5; 5(2):1-13.

19 Oberbeckmann S, Labrenz M. Marine Microbial Assemblages on Microplastics: Diversity, Adaptation, and Role in Degradation. Annual Review of Marine Science. 2020 Jan 3;12(1):209-32.

20 Weng Y-X, Jin Y-J, Meng Q-Y, Wang L, Zhang M, Wang Y-Z. Biodegradation behavior of poly (butylene adipate-coterephthalate) (PBAT), poly (lactic acid) (PLA), and their blend under soil conditions. Polymer Testing. 2013 Aug;32(5): 918-26.

21 Kim MY, Kim C, Moon J, Heo J, Jung SP, Kim JR. Polymer FilmBased Screening and Isolation of Polylactic Acid (PLA)-Degrading Microorganisms. Journal of Microbiol and Biotechnol. Korean Society for Microbiology and Biotechnology. 2017 Feb 28;27(2): 342-9.

22 Purwaningrum, P. Upaya Mengurangi Timbulan Sampah Plastik di Lingkungan. Indonesian Journal of Urban and Environmental Technology. 2016 Dec 6;8(2):141-7.

23 Hamlet C, Matte T, Mehta S. Combating Plastic Air Polution on Earth's Day. Vital Strategies Environmental Division. 2018.

24 Chandegara VK, Cholera SP, Nandasana JN, Kumpavat MT, Patel KC. Plastic Packaging Waste Impact on Climate Change and its Mitigation. In: Subbaiah R, Prajapati GV, Water management and climate smart agriculture. Adaptation of Climatic Resilient Water Management and Agriculture, Gyan Publishing House, New Delhi, India, 2015; 3: 404-15.

25 Halden RU. Plastics and Health Risk. Annual Review of Public Health. 2010 Apr 21;31:179-94
26 Pratomo H, Rohaeti E. Bioplastik Nata De Casava sebagai Bahan Edible Film Ramah Lingkungan. Jurnal Penelitian Saintek. 2011 Oct;16(2):172-90.

27 Wei R, Zimmermann W. Microbial Enzymes for the Recycling of Recalcitrant Petroleum-Based Plastics: How Far Are We? Microbial Biotechnology. 2017 Mar 28;10(6):1308-22.

28 Adamcová D, Vaverková M. Degradation of Biodegradable/Degradable Plastics in Municipal Solid-Waste Landfill. Polish Journal of Environmental Studies. 2014 Jan;23(4): 1071-8.

29 Marjayandari L, Shovitri M. Potensi Bakteri Bacillus sp. dalam Mendegradasi Plastik. Jurnal Sains dan Seni ITS. 2015;4(2):59-62.

30 Helbling C, Abanilla M, Lee L, Karbhari VM. Issues of variability and durability under synergistic exposure conditions related to advanced polymer composites in civil infrastructure. Composites Part A: Applied Science and Manufacturing. 2006 Aug;37(8):110210 .

31 Bonhomme S, Cuer A, Delort AM, Lemaire J, Sancelme M, Scott G. Environmental biodegradation of polyethylene. Polymer Degradation and Stability. 2003 Jan;81(3): 441-52.

32 Sharma B, Rawat H, Pooja, Sharma R. Bioremediation-A Progressive Approach toward Reducing Plastic Wastes. International Journal of Current Microbiology adn Applied Science. 2017 Dec 10;6(12):1116-31.

33 Gilan 1, Sivan A. Extracellular DNA Plays an Important Structural Role in the Biofilm of the Plastic Degrading Actinomycete Rhodococcus ruber. Advances in Microbiology. 2013;3(03):543-51.

34 Rosario LLD, Baburaj S. Isolation and Screening of Plastic Degrading Bacteria from Polythene Dumped Garbage Soil. International Journal for Research in Applied Science \& Engineering Technology. 2017;5(12):1028-32.

35 Tiwari AK, Gautam M and Maurya HK. Recent Development of Biodegradation Techniques of Polymer. International Journal of Research-GRANTHAALAYAH. 2018 Jun 30;6(6): 414-52.

36 Alshehrei F. Biodegradation of Low Density Polyethylene by Fungi Isolated from Red Sea Water. International Journal of Current Microbiology and Applied Sciences. 2017 Aug 10;6(8):1703-9.

37 Kyrikou J, Briassoulis D. Biodegradation of Agricultural Plastic Films: A Critical Review. Journal of Polymers and the Environment. 2007 Aug 1;15(3).

38 Leja K, Lewandowicz G. Polymer Biodegradation and Biodergadable Polymers-a Review. Polish Journal of Environmental Studies. 2010;19(2):255-66.

39 Ren L, Men L, Zhang Z, Guan F, Tian J, Wang B, Wang J, Zhang Y, Zhang W. Biodegradation of Polyethylene by Enterobacter $\mathrm{sp}$ D1 from the Guts of Wax Moth Galleria Mellonella. International Journal of Environtmental Research and Public Health. 2019 May 31;16(11):1-11

40 Saminathan P, Sripriya A, Nalini K, Sivakumar T, Thangapandian V. Biodegradation of Plastics by Pseudomonas putida isolated from Garden Soil Samples. Journal of Advanced Botany and Zoology. 2014 May 1;1(3):1-4.

41 Shahnawaz M, Sangale MK, Ade AB. Bacteria-based polythene degradation products: GC-MS analysis and toxicity testing. Environmental Science and Pollution ResearchEnviron. 2016 Feb $18 ; 23(11) ; 10733-41$.

42 Patil RC. Screening and Characterization of Plastic Degrading Bacteria from Garbage Soil. British Journal of Environmental Sciences. 2018;6(4):33-40.

43 Sriningsih A, Shovitri M. Potensi Isolat Bakteri Pseudomonas sebagai Pendegredasi Plastik. Jurnal Sains dan Seni ITS. 2015;4(2): 67-70.

44 Jumaah, O. S. Screening of Plastic Degrading Bacteria from Dumped Soil Area. Journal of Environmental Sinece, Toxicology and Food Technology. 2017 May;11(5): 93-8.

45 Shresta JK, Joshi DR, Regmi P, Badahit G. Isolation and Identification of Low Density Polyethylene (LDPE) Degrading 
Bacillus spp. from a Soil of Landfill Site. Acta Scientific Microbiology. 2019 Mar 5;2(4):30-4.

46 Deepika S, Madhuri JR. Biodegradation of Low Density Polyethylene by Microorganisms from Garbage Soil. Journal of Experimental Biology and Agricultural Science. 2015;3(1):15-21.

47 Riandi MI, Kawuri R, Sudirga SK. Potential of Pseudomonas sp. and Ochrobacterum sp. Isolated from Various Soil Sample as Degrading Bacteria of High Density Polyethylene (HDPE) and Low Density Polyethylene (LDPE) Plastic. SIMBIOSIS Journal of Biological Science. 2017 Sep 30;5(2):58-63.

48 Hussein AA, Al-Mayaly IK, Khudeir SH. Isolation, Screening and Identification of Low Density Polyethylene (LDPE) Degrading Bacteria from Contaminated Soil With Plastic Wastes. Mesopotamia Environmental Journal. 2015;1(4):1-14

49 Jamil SUU, Zada S, Khan I, Sajjad W, Rafiq M, Shah AA, Hasan F. Biodegradation of Polyethylene by Bacterial Strains Isolated from Kashmir Cave, Buner, Pakistan. Journal of Cave and Karst Studies. 2017;79(1): 73-80.

50 Delacuvellerie A, Cyriaque V, Gobert S, Benali S, Wattiez R. The Plastisphere in Marine Ecosystem Hosts Potential Specific Microbial Degraders Including Alcanivorax borkumensis as a Key Player for the Low Density Polyethylene Degradation. Journal of Hazardous Materials. 2019 Dec;380:1-11.

51 Duddu MK, Tripura KL, Gantuku G, Divya DS. Biodegradation of Low Density Polyethylene (LDPE) by a New BiosurfactantProducing Thermophilic Streptomyces coelicoflavus NBRC $15399^{\mathrm{T}}$ African Journal of Biotechnology. 2015;14(4):327-40.

52 Waithaka PN, Gathuru EM, Githaiga BM, Ochieng EO, Laban LT. Microbial Degradation of Polythene using Actinomycetes Isolated from maize Rhizosphere, Forest and Waste Damping Sites Within Egerton University, Kenya. International Journal on Emerging Technologies. 2017;8(1):05-10.

53 Helen AS, Uche EC, Hamid FS. Screening of Polyptopylene Degdradation Potential of Bacteria Isolated from Mangrove Ecosystems in Peninsular Malaysia. International Journal of Bioscience, Biochemistry and Bioinformatics. 2017;7(4): 245-251.

54 Asmita K, Shubhamsingh T, Tejashree S. Isolation of PIASTIC Degrading Microorganisms from Soil Samples Collected at Various Locations in Mumbai, India. International Research of Environetmental Sciences. 2015;4(3):77-85.

55 Yoshida S, Hiraga K, Takehana T, Taniguchi I, Yamaji H, Maeda J, Toyohara K, Miyamoto K, Kimura Y, Oda K. A bacterium that degrades and assimilates poly(ethylene terephthalate). Science. 2016 Mar 11;351(6278):1196-99.

56 Aly MM, Tork S, Qari HA, Al-Seeni MN. Poly- $\beta$-hydroxy butyrate Depolymerase from Streptomyces lydicus MM10, Isolated from Wastewater Sample. International Journal of Agriculture \& Biology. 2015 Sep 1;17(5):891-900.

57 Aburas MMA. Degradation of Poly (3-hydroxybuthyrate) using Aspergillus oryzae obtained from Uncultivated Soil. Life Science Journal. 2016;13(3):51-6.

58 Sekiguchi T, Sato T, Enoki M, Kanehiro H, Uematsu K, Kato C. Isolation and Characterization of Biodegradable Plastic Degrading Bacteria from Deep-Sea Environments. JAMSTEC Report of Research and Development. 2011;11:33-41.

59 Matsumura S. Mechanism of biodegradation. Biodegradable polymers for industrial applications. El Sevier. 2005; 357-410.

60 Ganesh P, Dineshraj D, Yoganathan K. Production and Screening of Depolymerasing Enzymes by Potential Bacteria and Fungi Isolated from Plastic Waste Dump Yard Sites. International Journal of Applied Research. 2017;3(3):693-695.

61 Hofrichter M, Lundell T, Hatakka A. Conversion of Milled Pine Wood by Manganese Peroxidase from Phlebia radiata. Applied and Environmental Microbiology. 2001 Oct 1;67(10):4588-93.

62 Bhardwaj H, Gupta R, Tiwari A. Microbial Population Associated with Plastic Degradation. Open Acces Scientific Reports. 2012; $1(5): 1-4$
63 Dashtban M, Schraft H, Syed TA, Qin W. Fungal Biodegradation and Enzymatic Modification of Lignin. International Journal of Biochemistry and Molecular Biology. 2010 May 23;1(1):36-50.

64 Lucas N, Bienaime C, Belloy C, Queneudec M, Silvestre F, NavaSaucedo J-E. Polymer biodegradation: Mechanisms and estimation techniques - A review. Chemosphere. Elsevier BV. 2008 Sep;73(4):429-42.

65 Dang TCH, Nguyen DT, Thai H, Nguyen TC, Tran TTH, Le VH, Nguyen VH, Tran XB, Pham TPT, Nguyen TG, Nguyen QT. Plastic Degradation by Thermophilic Bacillus sp. BCBT21 Isolated from Composting Agricultural Residual in Vietnam. Advances in Natural Sciences: Nanoscience and Nanotechnology. 2018 Mar 29;9(1):111.

66 Gautam R, Bassi AS, Yanful EK. A Review of Biodegradation of Synthetic Plastic and Foams. Applied Biochemistry and Biotechnology. 2007 Apr;141(1):85-108.

67 Khalil MI, Ramadan NA, Albarhawi RK. Biodegradation of Polymers by Fungi Isolated from Plastic Garbage and the Optimum Condition Assessment of Growth. J. Raff. Env. 2013 May;1(1):3343.

68 Austin HP, Allen MD, Donohoe BS, Rorrer NA, Kearns FK, Silveira RL, Pollard BC, Dominick G, Duman R, Omari KE, Mykhaylyk V, Wagner A, Michener WE, Amore A, Skaf MS, Crowley MF, Thorne AW, Johnson CW, Woodcock HL, McGeehan JE, Beckham GT. Characterization and Engineering of a Plasticdegrading Aromatic Polyesterase. Proceedings of the National Academy of Sciences. 2018 Apr 17;115(19):4350-7.

69 Howard GT, Ruiz C, Hillard NP. Growth of Pseudomonas chlororaphis on a polyester-polyurethane and the purification and characterization of a polyurethane-esterase enzyme. International Biodeterioration \& Biodegradation.1999 Mar;43(1-2):7-12.

70 Caruso G. Plastic Degrading Microorganisms as a Tool for Bioremediation of Plastic Contamination in Aquatic Environments. Journal of Pollution Effects\&Control. 2015;3(3): 1-2.

71 Phua SK, Castillo E, Anderson JM, Hiltner A. Biodegradation of a Polyurethane in vitro. Journal of Biomedical Materials Research. $1987 \mathrm{Feb} ; 21(2)$ : 231-46.

72 Kim DY, Rhee YH. Biodegradation of Microbial and Synthetic Polyesters by Fungi. Applied Microbiology and Biotechnology. 2003 Jan 25;61(4):300-8

73 Panagiotidou E, Konidaris C, Baklavaridis A, Zuburtikudis 1, Achilias D, Mitlianga P. A simple route for purifying extracellular poly3- hydroxybutyrate- depolymerase from Penicillium pinophilum. Enzyme Research. 2014 Sep 23; 2014:1-6.

74 Kawai F, Hu X. Biochemistry of microbial polyvinyl alcohol degradation. Applied Microbiology and Biotechnology. $2009 \mathrm{Jul}$ 10;84(2):227-37.

75 Tokiwa Y, Calabia BP, Ugwu CU, Aiba S. Biodegradability of Plastics. International Journal of Molecular Sciences. 2009 Aug 26;10(9):3722-42.

76 Tokiwa Y, Suzuki T. Hydrolysis of polyesters by lipases. Nature. Springer Science and Business Media LLC. 1977 Nov;270:76-8

77 Kim JM, Jeon CO. Isolation and Characterization of a New Benzene, Toluene, and Ethylbenzene Degrading Bacterium, Acinetobacter sp. B113. Current Microbiology. 2008 Oct 7;58(1):70-5.

78 Tomita K, Ikeda N, Ueno A. Isolation and characterization of a thermophilic bacterium, Geobacillus thermocatenulatus, degrading nylon 12 and nylon 66. Biotechnology Letter. 2004; 25:1743-6.

79 Bikiaris DN. Nanocomposites of aliphatic polyesters: An overview of the effect of different nanofillers on enzymatic hydrolysis and biodegradation of polyesters. Polymer Degradation and Stability. 2013 Sep;98(9):1908-28.

80 Râpă M, Popa ME, Cornea PC, Popa VL, Grosu E, Geicu-Cristea M, Stoica P, Tanase EE. Degradation Study by Trichoderma spp. of poly (3-hydroxybuthyrate) and Wood Fibers Composites. Romanian Biotechnological Letters. 2014;19(3): 9390-9. 
81 Vidali, M. Bioremediation. An Overview. Pure and Applied Chemistry. 2001 Jul 1;73(7): 1163-72.

82 Mukherjee, S. and S. Chatterjee. A Comparative Study of Commercially Available Plastic Carry Bag Biodegradation by Microorganisms Isolated from Hydrocarbon Effluent Enriched Soil. International Journal of Current Microbiology and Applied Sciences. 2014;3(5):318-325. 